\title{
Risk-Based Approaches to Food Safety Management International and Russian Experience
}

\author{
E.L.Bortsova \\ Ural State University of Economics \\ Ekaterinburg, Russia \\ borcovael@yandex.ru \\ N.A. Nikolaeva \\ Ural State University of Economics \\ Ekaterinburg, Russia \\ nikolayevana@mail.ru
}

\author{
L.Yu. Lavrova \\ Ural State University of Economics \\ Ekaterinburg, Russia \\ S.M. Bortsov \\ Ural State Medical University \\ Ekaterinburg, Russia
}

\begin{abstract}
International cooperation in the food market is currently characterized by the harmonization of international, supranational and national requirements for quality and safety of food products. Therefore, it is appropriate to talk about consistent requirements for ensuring food security at various levels of economic management.

We have considered the main directions of integration of Russian regulatory documents with international standards in the field of quality and safety of food products. We have also identified the directions of further integration in the light of the stated problems connected with harmonization of regulatory documents. Risk has been defined as a social system characterized by variability, alternativeness and contingency. The interdisciplinary mechanisms of food safety risk management have been described. The directions of further development of the manufacturer's liability insurance for the quality and safety of food products are determined.
\end{abstract}

Keywords: food safety, regulatory documents, risk-based approach, risk management, liability insurance

\section{INTRODUCTION}

A common approach to both international and supranational requirements in food safety is a risk-based approach. The logic of the risk-based approach provides the simultaneous solution of two issues. Firstly, it contributes the development of scientific and technological progress and the introduction of the latest food processing technologies. Secondly, it ensures compliance with the safety requirements for raw materials and finished products.

It is important to emphasize that supervision realized by state inspection bodies is given particular importance in introducing risk-based approach. As international practical experience of introduction of risk-oriented safety food products control shows, the evolution of regulatory documents requirements and their effective implementation supervision are the same both in international and Russian practice.

\section{LITERATURE REVIEW AND RESEARCH METHODS}

At the international level, food security is defined in a set of international Codex Alimentarius standards developed by the Food and Agriculture Organization of the United Nations, the World Trade Organization and the World Health Organization [1], [2], [3]. [4]. The objective of such standards is to create equal opportunities for countries regardless of their level of socio-economic development. For this reason, these documents describe the minimum acceptable yet mandatory requirements for food safety at all stages of food products life cycle [5], [6], [7], [8].

Currently, three levels of management are identified in the field of food safety. They are international, national, and regional (Table I) [9].

TABLE I. LEVELS OF RISK MANAGEMENT TO ENSURE FOOD SAFETY (THE AUTHOR'S TABLE)

\begin{tabular}{|l|l|l|}
\hline \multicolumn{2}{|c|}{ Level of Management } & \multicolumn{1}{c|}{ Coordinating Organizations } \\
\hline $\begin{array}{l}\text { inter- } \\
\text { national }\end{array}$ & global & $\begin{array}{l}\text { World Health Organization; } \\
\text { Food and Agriculture Organization of } \\
\text { the United } \\
\text { Codex Alimentarius Commission; }\end{array}$ \\
\cline { 2 - 4 } & supranational & $\begin{array}{l}\text { Commission on technical regulation, } \\
\text { sanitary, veterinary and phytosanitary } \\
\text { measures in trade at the Eurasian } \\
\text { Economic Community; }\end{array}$ \\
\hline national & $\begin{array}{l}\text { the Russian } \\
\text { Federation }\end{array}$ & $\begin{array}{l}\text { Federal Service for the Oversight of } \\
\text { Consumer Protection and Welfare; } \\
\text { Federal Service for Veterinary and } \\
\text { Phytosanitary Surveillance; }\end{array}$ \\
\hline regional & $\begin{array}{l}\text { Sverdlovsk } \\
\text { Region }\end{array}$ & $\begin{array}{l}\text { Office of the Federal Service for the } \\
\text { Oversight of Consumer Protection and } \\
\text { Welfare in the Sverdlovsk Region; } \\
\text { Office of the Federal Service for } \\
\text { Veterinary and Phytosanitary } \\
\text { Surveillance in the Sverdlovsk Region }\end{array}$ \\
\hline
\end{tabular}

Throughout the history of the creation of international standards in the field of food safety, a certain continuity and hierarchy of documents has developed. There are two groups of documents. The first group includes "specified" documents, the requirements of which apply to certain groups of food products. The second group of documents is "common-applicable", these documents contain requirements for all groups of food products.

Currently, unification of national and supranational requirements is going on due to participation of the Russian Federation in international economic integration, namely in the Eurasian Economic Union (EurAsEC). That finds its reflection in the development and adoption of mandatory documents such as technical regulations, which intend to fix food safety requirements. It is important to emphasize that the technical regulations of the EurAsEC take into account 
the continuity and hierarchy of the Codex Alimentarius standards. Although these technical regulations do not include requirements for all food groups yet and a full package of documents is still under development [10], [11], [12] (Table II).

TABLE II. DOCUMENTS ON FOOD SAFETY

\begin{tabular}{|c|c|c|}
\hline $\begin{array}{l}\text { Classificat } \\
\text { ion } \\
\text { Criterion }\end{array}$ & $\begin{array}{c}\text { Codex Alimentarius } \\
\text { Standards }\end{array}$ & $\begin{array}{c}\text { Technical Regulations } \\
\text { EurAsEC }\end{array}$ \\
\hline $\begin{array}{l}\text { "common- } \\
\text { applicable" } \\
\text { documents }\end{array}$ & 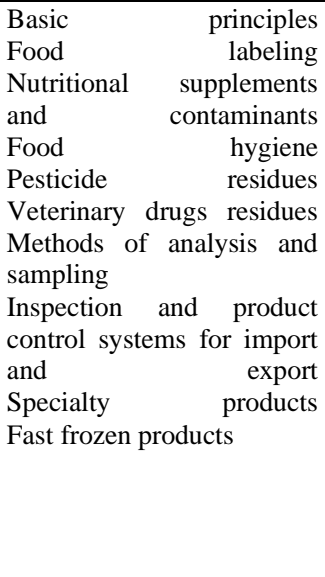 & $\begin{array}{l}\text { TR TS } 021 / 2011 \text { "On the } \\
\text { safety of food products" } \\
\text { TR TS 022/2011 "Food } \\
\text { products in terms of their } \\
\text { labeling" } \\
\text { TR TS 027/2012 "On } \\
\text { the safety of certain } \\
\text { types of specialty food } \\
\text { products, including } \\
\text { dietetic therapeutic and } \\
\text { preventive foods" } \\
\text { TR TS 029/2012 } \\
\text { "Safety requirements for } \\
\text { food additives, } \\
\text { flavorings and } \\
\text { technological aids" } \\
\text { TR TS 005/2011 "On } \\
\text { packaging safety" }\end{array}$ \\
\hline $\begin{array}{l}\text { "specified" } \\
\text { documents }\end{array}$ & 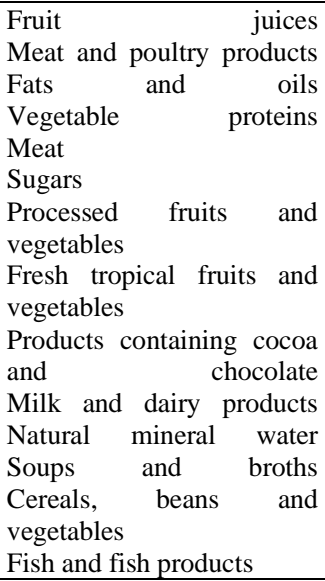 & $\begin{array}{l}\text { TR TS } 024 / 2011 \\
\text { "Technical regulations } \\
\text { for oil and fat products" } \\
\text { TR TS } 023 / 2011 \\
\text { "Technical regulations } \\
\text { for fruit and vegetable } \\
\text { juice products" } \\
\text { TR TS 015/2011 "On } \\
\text { the safety of grain" } \\
\text { TR TS 033/2013 "On } \\
\text { the safety of milk and } \\
\text { dairy products" } \\
\text { TR TS 034/2013 "On } \\
\text { the safety of meat and } \\
\text { meat products" }\end{array}$ \\
\hline
\end{tabular}

In addition, common supranational standards in the field of food product quality are being developed within the framework of the Eurasian Economic Community. Unlike international standards, which regulate minimum safety requirements and, in fact, allow low requirements in order to penetrate national markets, new quality standards lay the foundation for ensuring high living standards for all strata of population. They take into account the development of scientific and technological progress in food industry, processing industry and agribusiness [13], [14].

At the state level in the Russian Federation, ensuring the safety and quality of food products was interpreted differently until now. Prior to the adoption of the Federal Law of 27.12.2002, the categories of quality and safety of food products were not divided in regulatory documents (e.g. see Federal Law of 02.01. 2000 No. 29-FZ "On Quality and Food Safety".

However, with the adoption of legislation on technical regulation in the framework of harmonization of requirements with international standards, safety becomes an object of state oversight. At the same time, quality is seen as a market category and it becomes more and more difficult for state executive bodies to hold companies accountable for low-quality products.

The existing probability of turnover of inappropriate food products and their purchasing by consumers confirms this assumption. Fig. 1 shows data on counterfeit products sold in 2017.

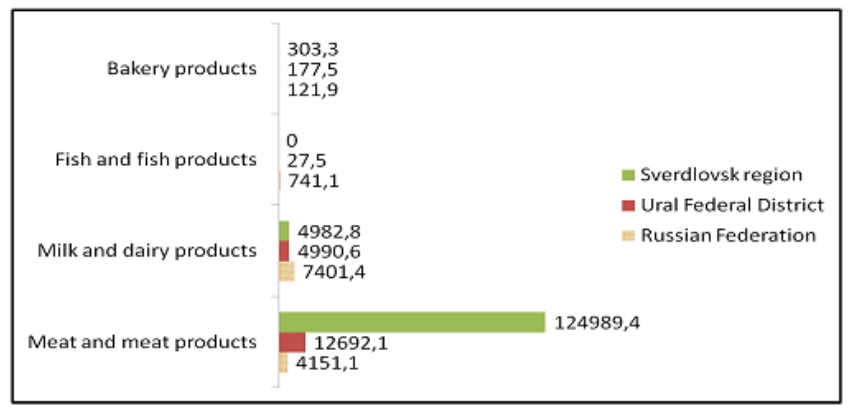

Fig. 1. Counterfeit products (in rubles per person)

We determine the volume of counterfeit products in circulation from the results of laboratory studies and from the turnover for food groups. In Fig. 1 it is seen that there is a high risk of consumption of counterfeit products in such groups as meat and meat products. Typical discrepancies of counterfeit products are inaccurate labeling and lack of supporting documents confirming product quality [10].

Violations of the requirements for product labeling committed by the manufacturer create the prerequisites for the circulation of low-quality and unsafe products and hence for the risks to consumers' life and health (Fig. 2) [15].

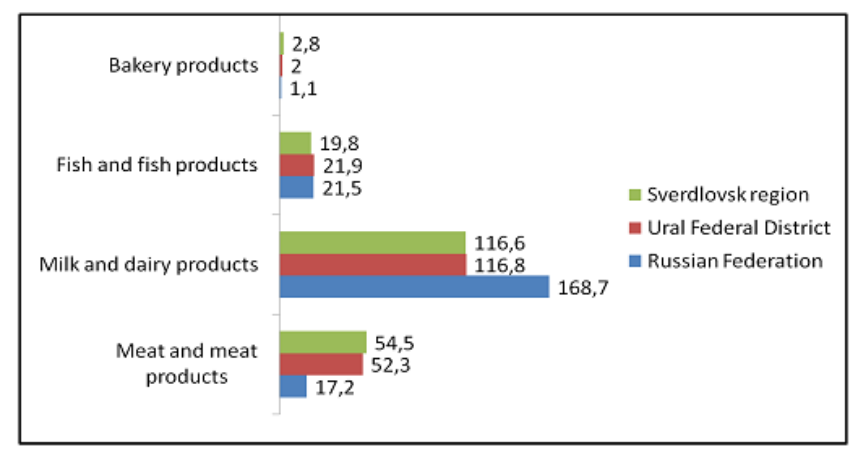

Fig. 2. Consumption of counterfeit products (in kilos per person per year)

The calculation of the volume of counterfeit products in circulation is determined based on the average indicators of non-compliance established as a result of laboratory studies conducted by Rospotrebnadzor and the average annual consumption of food products by one consumer.

Surveys conducted by the authors of the article indicate that consumers delegate control of their right to information about the properties and characteristics of products to supervisory state bodies. Consumers are inclined to consider it to be a benefit, since they believe the products sold to comply with the requirements of regulatory documents thanks to existence of these specialized supervisory authorities [16].

To fulfill the lack of real mechanisms in the field of consumer protection and the lack of demand for marketbased tools "The Strategy of Improvement of Food Products Quality in the Russian Federation until 2030" was adopted. 
In this document both safety and quality of food products are equally subject to supervision.

\section{RESULTS}

For the first time, risk as a tool for managing food safety appeared in the Russian Federation regulatory documents in the legislation on technical regulation. It was defined as the probability of harming citizens' life or health. Due to the fact that the risk category is inseparably connected with an individual, it is necessary to consider risk as an element of a social system characterized by variability, alternativeness and contingency. One can characterize risk in terms of ontological, epistemological and axiological aspects.

The ontological context of risk is based on inconsistency, which leads to variability and development. With system instability, alternative development opportunities appear. In the case of prosecution, this means contradictions between the requirements of national sanitary legislation and the legislation of the Eurasian Economic Union. Such a contradiction may result in a different degree of administrative responsibility, different sizes of fines and opportunities for agreements with representatives of supervision. Administrative responsibility in case of violation of national sanitary rules may be up to 20.000 rubles (Art. 6.3 Administrative Code). Administrative responsibility in case of violation of technical regulations of the Eurasian Economic Community may be up to 300.000 rubles (Art. 14.43 of the Code of Administrative Offenses) for the same discrepancies [17].

The epistemological context describes how the external uncertainties of a social system affect the uncertainty of the supervising system. For example, there is no clear uniform law enforcement practice of prosecution, as there is subjectivity in the interpretation of discrepancies between the national sanitary legislation, and the legislation on technical regulation of the Eurasian Economic Community. This creates uncertainty when assessing risk as a mandatory requirement and holding liable in case of violation. So the size of fines depends significantly on which segment of the catering business the subject belongs to. If it is a school or medical canteen, then the size of fine will be less as it is issued to the official under the national sanitary legislation. This is due to public recognition of the social function that canteens at hospitals and schools perform.

The axiological context suggests that changes in the social system are interpreted differently by each of its subjects depending on value attitudes. This leads to multidirectional and contradictory actions of the subjects. Actually, unequal supervisory measures are applied to small and medium-sized businesses in connection with "supervisory holidays". At the same time, most of the players of the catering services market belong to this preferential category of business, not social catering.

\section{DISCUSSION}

Risk as a tool for managing food safety is associated with many areas of activity (legal, sanitary, technical). So, it suggests the need for multidisciplinary approaches to managing it.

Interdisciplinary approaches are complex and involve the use of the following regulatory mechanisms: legal, medical (expert), technical and economic. Let us consider each of the presented mechanisms separately.
The legal mechanism plays an important framework role in shaping the legitimacy of the processes of changing national legislation and its integration with international practices. Currently, legislation in the field of food safety includes sanitary legislation, legislation on consumer protection and technical regulation. In addition, other bylaws provide for administrative and civil liability of business entities for violation of requirements. At present, as it has been noted, there are problems in law enforcement practice, since not all market entities, especially representatives of small and medium-sized businesses, as well as social enterprises, are able to meet changing requirements. In the authors' opinion, at the stage of the transition period, it is essential to determine the law enforcement practice taking into account international experience in the field of food safety management.

The medical risk management mechanism implements expert methods in food safety risk management, as it includes a set of sanitary rules and hygienic standards (national sanitary legislation) and technical requirements (technical regulation legislation). The evidence base for fulfilling safety requirements is a laboratory testing to confirm compliance. This applies not only to the safety of products, but to the safety of objects of working environment and infrastructure as well [18].

Regarding the technical mechanisms of food safety risk management, three basic concepts of risk management are applied: hazard management, uncertainty management and opportunity management.

Hazard management is defined as a system of preventive actions aimed at ensuring the quality of products and services, reliability and safety of production processes. This concept is reflected in Federal Law No. 184 "On Technical Regulation" and GOST ISO 22000-2007 "Food Safety Management System. Requirements for Organizations in the Food Production Chain".

Uncertainty management is for identifying hazardous events, their consequences, probability of occurrence. It also describes the factors that influence the reduction of the adverse consequences, as well as reducing the likelihood of a hazard. This conceptual approach is reflected in GOST ISO/IEC 31010-2011 "Risk Management. Evaluation Methods".

Opportunity management describes the requirements in order to create the conditions for the production of safe products. It is important to emphasize that the requirements take into account the hazard groups according to the HACCP system, which is the basis of TR TS 021/2011 "On food safety". There are four of them: biological, chemical, and physical hazards and allergens. It is only logical to analyze hazards within the product life cycle, starting from the development stage and up to selling and disposal of food products.

The economic risk management mechanism forms the management logic which is based on the costs of ensuring the safety of food products. This is reflected in GOST R ISO 10014-2008 “Organization Management. Guidelines for Achieving Economic Benefits in the Quality Management System". The economic risk management mechanism provides for compensation for damage in case of deviations in the quality or safety of food products. According to representatives of public consumer organizations, the key 
problem of the effectiveness of the current legislation on consumer protection is mass non-enforcement of court decisions taken in favour of consumers. According to the Union of Consumers of the Russian Federation, on average, half of court decisions on claims filed through public organizations have not been enforced over the past 3 years. Thus, compensation for harm provided by the legislation on the protection of consumer rights does not occur [19].

In this regard, foreign experience in protecting consumer rights is of interest. It provides for the use of liability insurance as a pre-trial tool to compensate consumers for damage.

The bringing to civil liability for causing harm may be carried out in the following cases:

- the product does not meet safety requirements;

- not correct product declaration;

- violations in product labeling.

In foreign practice, when insuring civil liability of producers, sellers, food safety performers, the following damages are compensated to the injured party:

- damage from combining, mixing raw materials;

- property and physical damage caused due to the lack of necessary properties of the goods;

- damage from further processing of low-quality products;

- damage from installation and dismantling of equipment;

- damage from poor-quality equipment;

- costs of product expertise [20].

In connection with the use of risk as a tool for managing safety of food likely to have a hazard, a draft of a Federal Law "On Compulsory Sanitary and Epidemiological Insurance" is being discussed. The insurance object is considered to be "manufacturer's (seller's, performer's) insurance of liability arising from harm to life, health or property of individuals or legal entities or the environment, due to activities related to operating, service providing, production, transportation, storage and sale of food products".

Insurance can become a tool to cover damage in case of violation of consumer rights. Liability insurance for quality and safety of food products include the following benefits: possibility of pre-trial settlement of the issue, guarantee of compensation, delegation of compensation issues to insurance companies, additional control over the safety of food products by insurance organizations through examinations and audits.

\section{CONCLUSION}

The main directions of integration of Russian regulatory documents with international standards in the field of quality and safety of food products have been discussed. The directions of further integration in the light of the stated problems connected with harmonization of regulatory documents have been identified. Risk has been defined as a social system characterized by variability, alternativeness and contingency. The interdisciplinary mechanisms of food safety risk management have been described. Manufacturer's liability insurance for food quality and safety is an important risk management tool for a market economy. Thus, it is important to determine further directions for its development.

\section{REFERENCES}

[1] H. King and W. Bedale, "Hazard analysis and risk-based preventive controls: improving food safety in human food manufacturing for food businesses," Academic Press Ltd-Elsevier Science Ltd London, England, 2018.

[2] J. Trafialek and W. Kolanowski, "Implementation and functioning of HACCP principles in certified and non-certified food businesses a preliminary study", British Food Journal, vol. 4, 2017, pp. 710-728.

[3] Zaidi Guoa, Li Bai, and Shunlong Gong, "Government regulations and voluntary certifications in food safety in China," A review, Trends in Food Science and Technology, vol. 90, August 2019, pp. $160-165$.

[4] T. Becker, "The Economics of Food Quality Standards," Institute for Agricultural Policy and Markets, 1999.

[5] I. Dodevska, M. Dodevska, M. Simic, V. Matovic, and I. Djekic, "A decade of sulphite control in Serbian meat industry and the effect of HACCP," Food Additives and Contaminants Part B-Surveillance, vol. 11, 2018, pp. 49-53.

[6] Ph. Hampton, "Reducing administrative burdens: effective inspection and enforcement," The Hampton Review - Final Report, March 2005, 140 p.

[7] V. Ramalho, A. P. de Moura, and L. M. Cunha, "Why do small business butcher shops fail to fully implement HACCP," Food Control, vol. 49, 2015, pp. 85-91.

[8] R. Wang, "Analysis on the Business Administration Problems in Market Supervision and the Countermeasures," Advances in Social Science Education and Humanities Research, Proceedings of the 2016 2nd International Conference On Social Science and Technology Education (ICSSTE 2016), vol. 55, 2016, pp. 1000-1004.

[9] Rukovodstvo po proverke pishchevyh produktov na osnove ocenki riskov, Risk assessment based food inspection guidelines, Rim: FAO, 2010.

[10] V. B. Gurvich, T. V. Mazhaeva, N. G. Sheluncova, E. R. Absatarova, V. I. Kozubskaya, S. V. Sinicyna, and E. L. Borcova, "Primenenie risk-orientirovannogo podhoda pri organizacii i provedenii nadzornyh meropriyatij za proizvodstvom i oborotom pishchevoj produkcii", Application of a risk-based approach during the organization and conduct of supervisory measures for the production and circulation of food products, Ekaterinburg: FBUN EMNC POZRPP Rospotrebnadzora, 2016.

[11] I. Chernukha, O. Kuznetsova, and V. Sysoy, "Hazard analysis and risk assessment in meat production practice in Russian Federation," Hazard analysis and risk assessment in meat production practice in Russian Federation, Procedia Food Science Belgrade, 58th International Meat Industry Conference (MeatCon), Serbia, vol. 5, 2015, pp. 42-45.

[12] G. G. Onishchenko, A. Yu. Popova, and N. V. Zajceva, "Analiz riska zdorov'yu $\mathrm{V}$ zadachah sovershenstvovaniya sanitarnoepidemiologicheskogo nadzora v Rossijskoj Federacii," Health risk analysis for improving sanitary and epidemiological surveillance in the Russian Federation, zhurnal Analiz riska zdorov'yu, vol. 2, 2014, pp. 4-13.

[13] E. L. Borcova and L. Yu. Lavrova, "Ispol'zovanie risk-menedzhmenta v upravlenii kachestvom i bezopasnost'yu molochnoj produkcii," Use of risk management in managing the quality and safety of dairy products, Molochnaya promyshlennost', 10, 2017, pp. 8-10.

[14] E. L. Borcova and L. Yu. Lavrova, "Proslezhivaemost' kak instrument upravleniya riskom na puti obespecheniya kachestva i bezopasnosti molochnoj produkcii," Traceability as a risk management tool for ensuring the quality and safety of dairy products, Molochnaya promyshlennost', no. 2, 2018, pp. 18-21.

[15] E. L. Borcova, L. Yu. Lavrova, "Markirovka molochnoj produkcii i sistema cennostej potrebitelej", Molochnaya promyshlennost', Labeling of dairy products and the system of consumer values, no. 12, 2018, pp. 19-20.

[16] M. Yu. Malkina, "Institucional'nye osnovy snizheniya kachestva tovarov i uslug v usloviyah rynochnoj ekonomiki (otvet I. V. Rozmainskomu)," Institutional foundations for reducing the quality of goods and services in a market economy (response to I. V. Rozmainsky), Zhurnal institucional'nyh issledovanij, vol. 6, 2014, pp. 77-97. 
analysis and critical control points in catering, Hygiene and sanitation, t. 96, no. 12, 2017, pp. 1151-1154.

[19] S. V. Sinicyna, V. I. Kozubskaya, T. V. Mazhaeva, and E. L. Borcova, "Pitanie kak faktor riska professional'noj zabolevaemosti rabotnikov metallurgicheskogo proizvodstva i mery profilaktiki," Nutrition as a risk factor for occupational morbidity in metallurgical workers and preventive measures, Zdorov'e naseleniya i sreda obitaniya, no. 9, 2019, pp. 13-17.

[20] V. N. Prosvetov, "Obzor evropejskoj sistemy strahovaniya obyazatel'noj otvetstvennosti za product," Overview of the European Compulsory Product Liability Insurance System, M.: TEIS, 2005. 